\title{
Role of ataxia-telangiectasia mutated in hydrogen peroxide preconditioning against oxidative stress in Neuro-2a cells
}

\author{
JIANHUA WU $^{1 *}$, FANG WANG ${ }^{1 *}$, ZHIQIANG SU ${ }^{2}$, JUE LIU $^{3}$, \\ SANG HU ${ }^{1}, \mathrm{HAO} \mathrm{LI}^{1}$, PEI HU${ }^{1}$ and DONGFANG WU ${ }^{1}$ \\ ${ }^{1}$ Department of Pharmacy, Zhongnan Hospital of Wuhan University, Wuhan, Hubei 430071; \\ ${ }^{2}$ Department of Pharmacy, The First Affiliated Hospital of Guangzhou University of Traditional Chinese Medicine, \\ Guangzhou, Guangdong 510405; ${ }^{3}$ Department of Pharmacy, The Central Hospital of Wuhan, Tongji Medical College, \\ Huazhong University of Science and Technology, Wuhan, Hubei 430014, P.R. China
}

Received December 16, 2015; Accepted January 27, 2017

DOI: $10.3892 / \mathrm{mmr} .2017 .6510$

\begin{abstract}
Ischemic preconditioning is an endogenous protective mechanism that may be triggered by exposure to hydrogen peroxide $\left(\mathrm{H}_{2} \mathrm{O}_{2}\right)$. However, the exact mechanisms underlying preconditioning remain to be fully understood. Ataxia-telangiectasia mutated (ATM) is regarded as an essential endogenous protective protein against stress. The aim of the present study was therefore to investigate whether ATM mediates $\mathrm{H}_{2} \mathrm{O}_{2}$ preconditioning. Preconditioning of Neuro-2a (N2a) cells with $100 \mu \mathrm{M} \mathrm{H}_{2} \mathrm{O}_{2}$ for 90 min resulted in protection from injury induced by a long period of exposure to $600 \mu \mathrm{M} \mathrm{H}_{2} \mathrm{O}_{2}$. In addition, preconditioning with $100 \mu \mathrm{M}$ $\mathrm{H}_{2} \mathrm{O}_{2}$ activated ATM and increased ATM mRNA and protein expression levels in N2a cells. Furthermore, the protective effects induced by $\mathrm{H}_{2} \mathrm{O}_{2}$ preconditioning were attenuated by pretreatment with the ATM inhibitor, Ku55933, or ATM small interfering RNA. In conclusion, these findings suggested that ATM is involved in $\mathrm{H}_{2} \mathrm{O}_{2}$ preconditioning-mediated protection against oxidative stress-induced injury in N2a cells. To the best of our knowledge, the present study demonstrated, for the first time, that the ATM protein is a key mediator of $\mathrm{H}_{2} \mathrm{O}_{2}$ preconditioning.
\end{abstract}

\section{Introduction}

Ischemic preconditioning is an endogenous protective mechanism whereby tissue subject to single or multiple brief episodes of ischemia/reperfusion develops protection against

Correspondence to: Professor Dongfang $\mathrm{Wu}$, Department of Pharmacy, Zhongnan Hospital of Wuhan University, 169 Dong-Hu Road, Wuhan, Hubei 430071, P.R. China

E-mail:dfwu2010@whu.edu.cn

*Contributed equally

Key words: ataxia-telangiectasia mutated, preconditioning, hydrogen peroxide subsequent potentially lethal ischemic injury. Previous studies have demonstrated that preconditioning is additionally triggered by non-ischemic stress, including exposure to reactive oxygen species (ROS) $(1,2)$. However, the exact mechanisms underlying preconditioning remain to be fully understood.

Ataxia-telangiectasia mutated (ATM) serine/threonine kinase is a member of a superfamily of phosphatidylinositol (PI) 3-kinase-like kinases (3) and is regarded as a lynchpin of cellular defenses to stress, particularly antioxidative stress, maintaining cellular redox homeostasis (4). Previous studies have reported that ATM-deficient mice have increased levels of ROS, particularly in the nervous system, leading to neuronal degeneration $(5,6)$. In addition, it has been reported that activation of ATM in the cytoplasm protects neurons against oxidative stress-induced damage (7). Patients with ataxia telangiectasia, carrying mutations at the two ATM alleles $\left(\mathrm{ATM}^{-} /\right)$, present with progressive cerebellar ataxia and cerebellar degeneration $(8,9)$. There is accumulating evidence to suggest that ATM is a central regulator of the response to DNA damage, including DNA repair, telomere maintenance and regulation of the cell cycle (10-12). Although ATM is expressed in the brain and neurons (13), its involvement in preconditioning remains to be investigated. The present study investigated whether $\mathrm{H}_{2} \mathrm{O}_{2}$ preconditioning protected against injury induced by oxidative stress in Neuro-2a (N2a) cells, and the role of ATM in $\mathrm{H}_{2} \mathrm{O}_{2}$ preconditioning.

\section{Materials and methods}

Cell culture and treatment. N2a mouse neuroblast cells (Sigma-Aldrich; Merck KGaA, Darmstadt, Germany) were cultured in high-Dulbecco's modified Eagle's medium/OPTI-Minimal Essential Medium (1:1; Gibco; Thermo Fisher Scientific, Inc., Waltham, MA, USA) containing $5 \%$ (v/v) fetal bovine serum (Gibco; Thermo Fisher Scientific, Inc.) in a humidified atmosphere of $5 \% \mathrm{CO}_{2}$ at $37^{\circ} \mathrm{C}$. Cells were passaged by trypsinization and seeded at $\sim 10^{5}$ cells $/ \mathrm{ml}$. When cells reached $60-80 \%$ confluence, the culture medium was replaced with serum-free medium for 12-24 h. Cells were initially treated with 20, 50, 100, 300, 600 and $1,000 \mu \mathrm{M} \mathrm{H}_{2} \mathrm{O}_{2}$ for $12 \mathrm{~h}$ to assess the effect of different doses of $\mathrm{H}_{2} \mathrm{O}_{2}$ on 
$\mathrm{N} 2 \mathrm{a}$ cell viability. The results of this treatment indicated that $600 \mathrm{uM} \mathrm{H}_{2} \mathrm{O}_{2}$ was the median lethal dose. Therefore, $600 \mu \mathrm{M}$ $\mathrm{H}_{2} \mathrm{O}_{2}$ was used for subsequent experiments. Subsequently, cells were pretreated with $100 \mu \mathrm{M} \mathrm{H}_{2} \mathrm{O}_{2}$ for 90 min followed by $12 \mathrm{~h}$ recovery and subsequent exposure to the median lethal dose of $600 \mu \mathrm{M} \mathrm{H}_{2} \mathrm{O}_{2}$ for $12 \mathrm{~h}$. To evaluate the involvement of ATM in preconditioning-induced protection, additional experiments were performed. N2a cells were treated with $10 \mu \mathrm{M}$ ATM-specific inhibitor Ku55933 (Sigma-Aldrich; Merck $\mathrm{KGaA}$ ) for $30 \mathrm{~min}$ or transfected with ATM small interfering RNA (siRNA) for $36 \mathrm{~h}$ prior to $\mathrm{H}_{2} \mathrm{O}_{2}$ preconditioning. Following $\mathrm{H}_{2} \mathrm{O}_{2}$ preconditioning, these cells were subjected to the lethal dose of $600 \mu \mathrm{M} \mathrm{H}_{2} \mathrm{O}_{2}$.

Assessment of cell viability. An MTT assay was used to determine cell viability. N2a cells were seeded at a density of $1 \times 10^{4}$ cells/well in a 96 -well culture plate. At the end of each experiment, $10 \mu 1 \mathrm{MTT}(0.5 \mathrm{mg} / \mathrm{ml})$ was added to the cell medium and incubated for $4 \mathrm{~h}$ at $37^{\circ} \mathrm{C}$. Following incubation, MTT solutions were removed, dimethyl sulfoxide was added, and the absorbance at $490 \mathrm{~nm}$ was measured using a microplate reader. Data are expressed as a percentage of the control, which was considered to be $100 \%$ viable.

siRNA transfection. N2a cells were transfected with $50 \mathrm{nM}$ ATM siRNA or Scramble control siRNA using Lipofectamine $2000{ }^{\circledR}$ reagent (Invitrogen; Thermo Fisher Scientific, Inc.), according to the manufacturer's protocol. The siRNA sequences utilized targeted the following mouse ATM coding sequence: 5'-GCTTGAGGCTGATCCATATTC-3'. To determine the effect of siRNA transfection, the N2a cells were collected and lysed with lysis buffer [50 mM NaCl, $10 \mathrm{mM}$ Tris-base, $1 \mathrm{mM}$ EDTA, $2 \mathrm{mM}$ sodium orthovanadate $\left(\mathrm{Na}_{3} \mathrm{VO}_{4}\right), 1 \mathrm{mM} \mathrm{NaF}$, $1 \mathrm{mM}$ phenylmethyl-sulfonyl fluoride, $1 \%$ sodium dodecyl sulfate (SDS)] at $95^{\circ} \mathrm{C}$ for $10 \mathrm{~min}$ for western blot analysis $48 \mathrm{~h}$ following transfection.

$R T-q P C R$. Total cellular RNA was isolated using TRIzol ${ }^{\circledR}$ reagent (Invitrogen; Thermo Fisher Scientific, Inc.) and cDNA was generated from $1 \mu \mathrm{g}$ total RNA using the M-MLV reverse transcription kit (Promega Corporation, Madison, WI, USA). Quantification of gene copies was performed using the ABI 7300 Real-Time PCR system (Applied Biosystems; Thermo Fisher Scientific, Inc.) with the Power SYBR ${ }^{\circledR}$ Green PCR Master Mix kit (Promega Corporation). The primer sequences used were as follows: Forward, 5'-GCACACGGATTGCTC AAGGA-3' and reverse, 5'-GCCCATTCGGAATATGGA TCAG-3' for ATM (14); and forward, 5'-CAATGACCCCTT CATTGA-3' and reverse, 5'-GACAAGCTTCCCGTTCTC AG-3' for GAPDH (15). The following thermocycling conditions were used: An initial predenaturation step at $95^{\circ} \mathrm{C}$ for $10 \mathrm{~min}$, followed by 40 cycles of denaturation at $95^{\circ} \mathrm{C}$ for $15 \mathrm{sec}$ and annealing at $60^{\circ} \mathrm{C}$ for $60 \mathrm{sec}$. All amplification reactions for each sample were repeated in at least triplicate, and the relative expression values were normalized to those of GAPDH using the $2^{-\Delta \Delta \mathrm{Cq}}$ method (16).

Western blot analysis. Cells were lysed with lysis buffer [50 mM NaCl, $10 \mathrm{mM}$ Tris-base, $1 \mathrm{mM}$ EDTA, $2 \mathrm{mM} \mathrm{Na}_{3} \mathrm{VO}_{4}$, $1 \mathrm{mM} \mathrm{NaF}, 1 \mathrm{mM}$ phenylmethyl-sulfonyl fluoride, $1 \% \mathrm{SDS}]$, and the protein content of the lysates was measured using the bicinchoninic acid assay. Subsequently, $40 \mu \mathrm{g} /$ lane protein was separated by $7.0 \%$ SDS-polyacrylamide gel electrophoresis and electrophoretically transferred to a nitrocellulose membrane. The membranes were blocked with $5 \%$ bovine serum albumin (Beyotime Institute of Biotechnology, Haimen, China) in TBS containing $1 \%$ Tween 20 at room temperature for $1 \mathrm{~h}$, and incubated with ATM (mouse monoclonal antibody; dilution, 1:1,000; cat. no. sc-47739; Santa Cruz Biotechnology, Inc., Dallas, TX, USA), phosphorylated (p)-ATM antibodies (mouse monoclonal antibody; dilution, 1:500; cat. no. sc-73615; Santa Cruz Biotechnology, Inc.) and $\beta$-actin (rabbit polyclonal antibody; dilution, 1:1,000; cat. no. sc-130656; Santa Cruz Biotechnology, Inc.) at $4{ }^{\circ} \mathrm{C}$ overnight, followed by incubation with a horseradish peroxidase-conjugated secondary antibody (either goat anti-rabbit; dilution, 1:1,000; cat. no. A0208. Or goat anti-mouse; dilution, 1:1,000; cat. no. A0216; Beyotime Institute of Biotechnology) for $1 \mathrm{~h}$ at room temperature. The immunostaining was visualized by enhanced chemiluminescence (Beyotime Institute of Biotechnology). The blots were scanned, and the pixel count and intensity of each band was quantified using the Scion Image software (version 4.2.3.2; Scion Corporation, Frederick, MD, USA). The results were normalized to $\beta$-actin expression.

Flow cytometric analysis of apoptosis. Flow cytometry was performed as described in a previous study by Tang et al (1). Briefly, treated N2a cells $\left(2 \times 10^{6}\right)$ were collected and centrifuged at $5,000 \times \mathrm{g}$ at $4^{\circ} \mathrm{C}$ for $10 \mathrm{~min}$. The cell pellet was resuspended in cold PBS and fixed using $70 \%$ ethanol at $4^{\circ} \mathrm{C}$ for $1 \mathrm{~h}$. The cells were then centrifuged at 5,000 x $g$ for $10 \mathrm{~min}$, and resuspended in PBS. DNase-free RNaseA $(100 \mu \mathrm{l}, 200 \mu \mathrm{g} / \mathrm{ml})$ was added to the cells and incubated at $37^{\circ} \mathrm{C}$ for $10 \mathrm{~min}$. Cells were subsequently incubated with propidium iodide (PI) at a final concentration of $100 \mathrm{mg} / \mathrm{l}$, filtered and incubated in the dark at room temperature for $10 \mathrm{~min}$ prior to flow cytometric analysis. The PI fluorescence of individual nuclei was measured using a flow cytometer (Beckman-Coulter, Inc., Brea, CA, USA). DNA labeling data were analyzed using CellQuest v.3.0 sampling software (BD Biosciences, Franklin, NJ, USA) for flow cytometry.

Caspase-3 activity assay. Caspase-3 activity was measured using a colorimetric CaspACE kit (Promega Corporation) according to the manufacturer's protocol. Cells were lysed using the kit lysis buffer (Promega Corporation) and centrifuged for $5 \mathrm{~min}$ at $5,000 \times \mathrm{g}$ and $4^{\circ} \mathrm{C}$. The supernatant was used for the measurement of caspase- 3 activity.

Determination of 8-hydroxy-2'-deoxyguanosine (8-OHdG) in DNA. DNA was extracted from N2a cells with the DNA Extractor kit (Wako Pure Chemical Industries, Ltd., Osaka, Japan) according to the manufacturer's protocol. The extracted DNA was digested with 8 units nuclease P1 (Cell Biolabs, Inc., San Diego, CA, USA) for $2 \mathrm{~h}$ at $37^{\circ} \mathrm{C}$ in a final concentration of $20 \mathrm{mM}$ sodium acetate ( $\mathrm{pH} 5.2$ ), followed by treatment of 6 units alkaline phosphatase for $1 \mathrm{~h}$ at $37^{\circ} \mathrm{C}$ in a final concentration of $100 \mathrm{mM}$ Tris $(\mathrm{pH} 7.5)$. The reaction mixture was centrifuged for $5 \mathrm{~min}$ at $6,000 \times \mathrm{g}$ and $4^{\circ} \mathrm{C}$, and the supernatant was used for the 8-OHdG Quantitation ELISA assay (catalog 
no. STA-320; Cell Biolabs, Inc.), according to the manufacturer's protocol.

Statistical analysis. SPSS statistical software was used for statistical analysis (version 18.0; SPSS, Inc., Chicago, IL, USA). The data are expressed as the mean \pm standard error of at least 3 replicate experiments. Comparisons among multiple groups were performed using one-way analysis of variance followed by the Student-Newman-Keuls post hoc test. $\mathrm{P}<0.05$ was considered to indicate a statistically significant difference.

\section{Results}

Effect of $\mathrm{H}_{2} \mathrm{O}_{2}$ preconditioning on cell viability following oxidative stress. The effect of different concentrations of $\mathrm{H}_{2} \mathrm{O}_{2}$ on N2a cell viability was evaluated by MTT assay (Fig. 1). Treatment with 20-100 $\mu \mathrm{M} \mathrm{H}_{2} \mathrm{O}_{2}$ did not significantly affect N2a cell viability; however, concentrations of 300, 600 and $1,000 \mu \mathrm{M}$ significantly decreased $\mathrm{N} 2 \mathrm{a}$ cell viability compared with the control, to $78.5 \pm 6.5(\mathrm{P}<0.05), 44.2 \pm 3.5(\mathrm{P}<0.01)$ and $11.4 \pm 1.4 \%$ ( $\mathrm{P}<0.001)$, respectively. In addition, an MTT assay demonstrated that preconditioning cells with 50 or $100 \mu \mathrm{M}$ $\mathrm{H}_{2} \mathrm{O}_{2}$ attenuated the reduction of $\mathrm{N} 2 \mathrm{a}$ cell viability induced by $600 \mu \mathrm{M} \mathrm{H}_{2} \mathrm{O}_{2}$, compared with the non-preconditioned group $\left(\mathrm{P}<0.05\right.$ and $\mathrm{P}<0.01$, respectively; Fig. 2), with $100 \mu \mathrm{M} \mathrm{H}_{2} \mathrm{O}_{2}$ most effective. Preconditioning with $20 \mu \mathrm{M} \mathrm{H}_{2} \mathrm{O}_{2}$ failed to significantly attenuate the reduction in cell viability induced by treatment with $600 \mu \mathrm{M} \mathrm{H}_{2} \mathrm{O}_{2}$ (P>0.05; Fig. 2). Therefore, $100 \mu \mathrm{M} \mathrm{H}_{2} \mathrm{O}_{2}$ was selected for preconditioning in subsequent experiments.

$\mathrm{H}_{2} \mathrm{O}_{2}$ preconditioning decreases neuronal apoptosis, caspase-3 activity and 8-OHdG content. Following exposure of $\mathrm{N} 2 \mathrm{a}$ cells to $600 \mu \mathrm{M} \mathrm{H}_{2} \mathrm{O}_{2}$ for $12 \mathrm{~h}$, the percentage of apoptotic $\mathrm{N} 2 \mathrm{a}$ cells increased significantly compared with the control (62.8 \pm 5.2 vs. $6.5 \pm 0.5 \%$; $<<0.01$; Fig. 3). Preconditioning with $100 \mu \mathrm{M} \mathrm{H}_{2} \mathrm{O}_{2}$ for 90 min did not significantly alter the apoptotic rate compared with the control $(9.5 \pm 0.89$ vs. $6.5 \pm 0.5 \%$; $=5$; P>0.05; Fig. 3); however, subsequent $600 \mu \mathrm{M}$ $\mathrm{H}_{2} \mathrm{O}_{2}$-induced apoptosis was significantly inhibited following preconditioning compared with the non-preconditioned group (33.8 \pm 3.1 vs. $62.8 \pm 5.2 \%$, respectively; $n=5$; $P<0.01$; Fig. 3 ).

The caspase 3 protein is a member of the cysteine-aspartic acid protease (caspase) family (17). Sequential activation of caspases serves a central role in the execution-phase of cell apoptosis, thus caspase- 3 activity is a marker of cell apoptosis (18). Consistent with the results of flow cytometric analysis, caspase-3 activity was significantly decreased in $\mathrm{N} 2 \mathrm{a}$ cells preconditioned with $100 \mu \mathrm{M} \mathrm{H}_{2} \mathrm{O}_{2}$ and exposed to $600 \mu \mathrm{M} \mathrm{H}_{2} \mathrm{O}_{2}$ compared with the non-preconditioned group $(\mathrm{P}<0.01$; Fig. 4).

$8-\mathrm{OHdG}$ is a marker of oxidative stress (19). The present study observed that $8-\mathrm{OHdG}$ content was additionally significantly decreased in $\mathrm{N} 2$ a cells preconditioned with $100 \mu \mathrm{M} \mathrm{H}_{2} \mathrm{O}_{2}$ and exposed to $600 \mu \mathrm{MH}_{2} \mathrm{O}_{2}$ compared with the non-preconditioned group $(\mathrm{P}<0.01 ;$ Fig. 5).

Effect of $\mathrm{H}_{2} \mathrm{O}_{2}$ preconditioning on ATM expression. The effect of $100 \mu \mathrm{M} \mathrm{H}_{2} \mathrm{O}_{2}$ preconditioning on ATM mRNA and protein expression levels was determined. Preconditioning of N2a cells

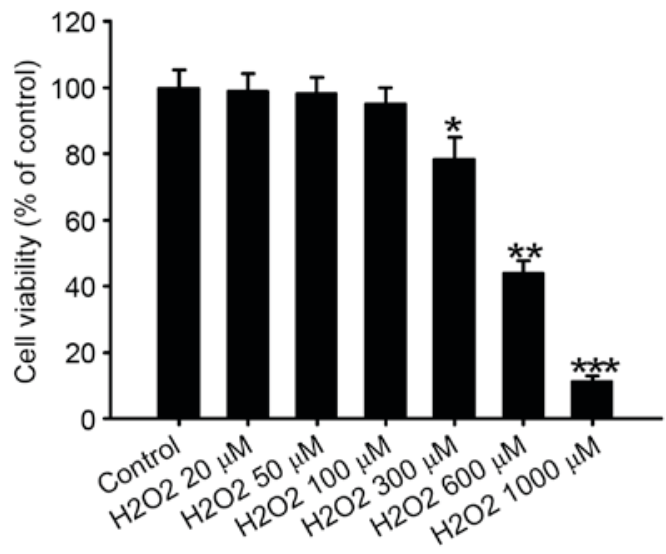

Figure 1. Effect of exposure to $\mathrm{H}_{2} \mathrm{O}_{2}$ on Neuro-2a cell viability. Data are expressed as the mean \pm standard error $(\mathrm{n}=5) .{ }^{*} \mathrm{P}<0.05,{ }^{* *} \mathrm{P}<0.01$ and *** $\mathrm{P}<0.001$ vs. control.

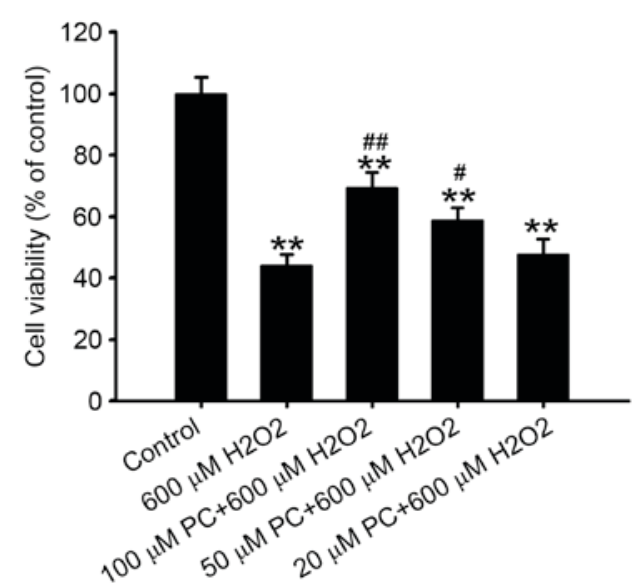

Figure 2. Effect of PC with $\mathrm{H}_{2} \mathrm{O}_{2}$ on Neuro-2a cell viability. Data are expressed as the mean \pm standard error $(\mathrm{n}=5) .{ }^{* *} \mathrm{P}<0.01$ vs. control; ${ }^{*} \mathrm{P}<0.05$ and ${ }^{\# \#} \mathrm{P}<0.01$ vs. $600 \mu \mathrm{M} \mathrm{H}_{2} \mathrm{O}_{2}$. PC, preconditioning.

with $100 \mu \mathrm{M} \mathrm{H}_{2} \mathrm{O}_{2}$ for 90 min significantly increased p-ATM protein expression levels compared with the control $(\mathrm{P}<0.01$; Fig. 6). Preconditioning with $100 \mu \mathrm{M} \mathrm{H}_{2} \mathrm{O}_{2}$ for $90 \mathrm{~min}$, then $12 \mathrm{~h}$ later, increased the expression of ATM mRNA and protein when compared with the control $(\mathrm{P}<0.01$; Fig. $7 \mathrm{~A}$ and $\mathrm{B})$.

ATM inhibition or knockdown attenuates the protective effect of $\mathrm{H}_{2} \mathrm{O}_{2}$ preconditioning. To determine the involvement of ATM in $\mathrm{H}_{2} \mathrm{O}_{2}$ preconditioning, RNA interference (RNAi) with siRNA, and treatment with an ATM inhibitor, was performed. siRNA-mediated knockdown of ATM resulted in reduction of ATM protein expression compared with the untransfected control and scramble control groups $(\mathrm{P}<0.01$; Fig. 8). When $\mathrm{N} 2 \mathrm{a}$ cells were incubated with $10 \mu \mathrm{mol} / 1 \mathrm{Ku} 55933$ for $36 \mathrm{~h}$ or transfected with $50 \mathrm{nM}$ control siRNA, the percentage of apoptotic cells was $8.0 \pm 0.68$ and $11.1 \pm 0.96 \%$, respectively, and were not significantly different compared with the control

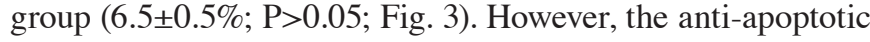
effect of preconditioning with $100 \mu \mathrm{M} \mathrm{H}_{2} \mathrm{O}_{2}$ was decreased by pretreatment with the ATM inhibitor Ku55933 or silencing of ATM with RNAi compared with the preconditioned group $(\mathrm{P}<0.01$ and $\mathrm{P}<0.01$, respectively; Fig. 3$)$. In addition, the 

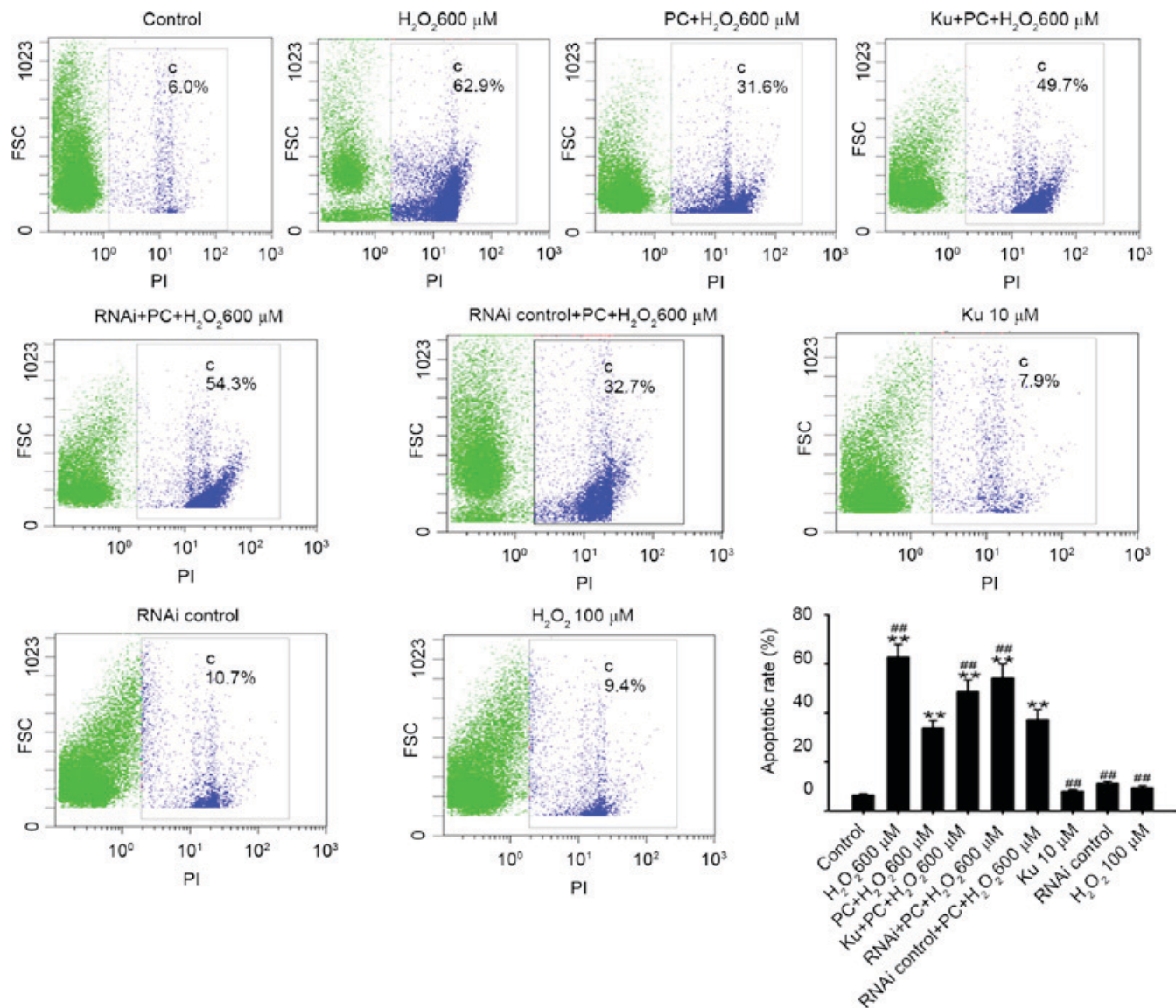

Figure 3. Effect of various treatments on apoptosis induced by $12 \mathrm{~h}$ exposure to $600 \mu \mathrm{M} \mathrm{H}_{2} \mathrm{O}_{2}$ in Neuro-2a cells, assessed by flow cytometry. Data are expressed as the mean \pm standard error $(\mathrm{n}=5)$. ${ }^{* *} \mathrm{P}<0.01$ vs. control; ${ }^{\# \#} \mathrm{P}<0.01$ vs. $\mathrm{PC}+600 \mu \mathrm{M} \mathrm{H}_{2} \mathrm{O}_{2}$. PI, propidium iodide; $\mathrm{PC}$, preconditioned with $100 \mu \mathrm{M} \mathrm{H}_{2} \mathrm{O}_{2} ; \mathrm{Ku}$, Ku55933; RNAi, RNA interference with small interfering RNA; RNAi control, control small interfering RNA.

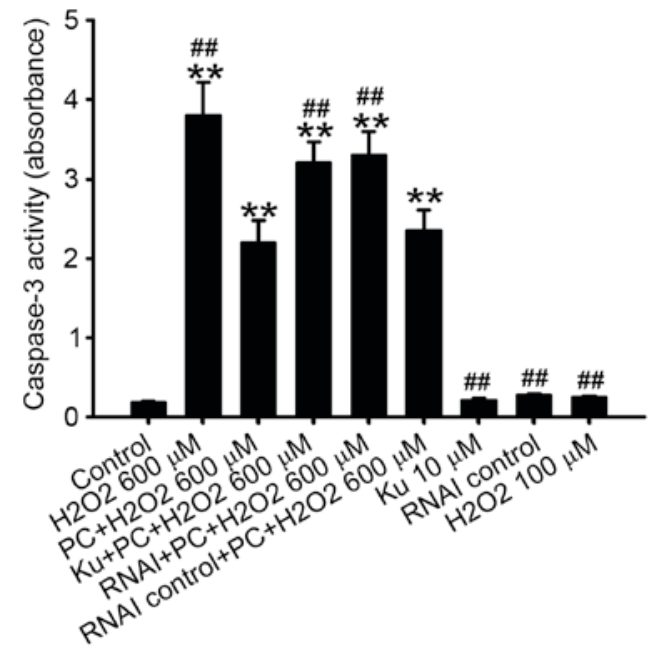

Figure 4. Effect of various treatments on caspase-3 activity in Neuro-2a cells following exposure to $600 \mu \mathrm{M} \mathrm{H}_{2} \mathrm{O}_{2}$, as assessed using a colorimetric CaspACE kit. Data are expressed as the mean \pm standard error $(\mathrm{n}=5) .{ }^{* *} \mathrm{P}<0.01$ vs. control; ${ }^{\# \#} \mathrm{P}<0.01$ vs. $\mathrm{PC}+600 \mu \mathrm{M} \mathrm{H}_{2} \mathrm{O}_{2}$. PC, preconditioned with $100 \mu \mathrm{M}$ $\mathrm{H}_{2} \mathrm{O}_{2} ; \mathrm{Ku}, \mathrm{Ku} 55933$; RNAi, RNA interference with small interfering RNA; RNAi control, control small interfering RNA.

decreased caspase-3 activity observed following preconditioning with $100 \mu \mathrm{M} \mathrm{H}_{2} \mathrm{O}_{2}$ was inhibited by the pretreatment of cells with the ATM inhibitor Ku55933 or silencing of ATM with RNAi compared with the preconditioned group $(\mathrm{P}<0.01$

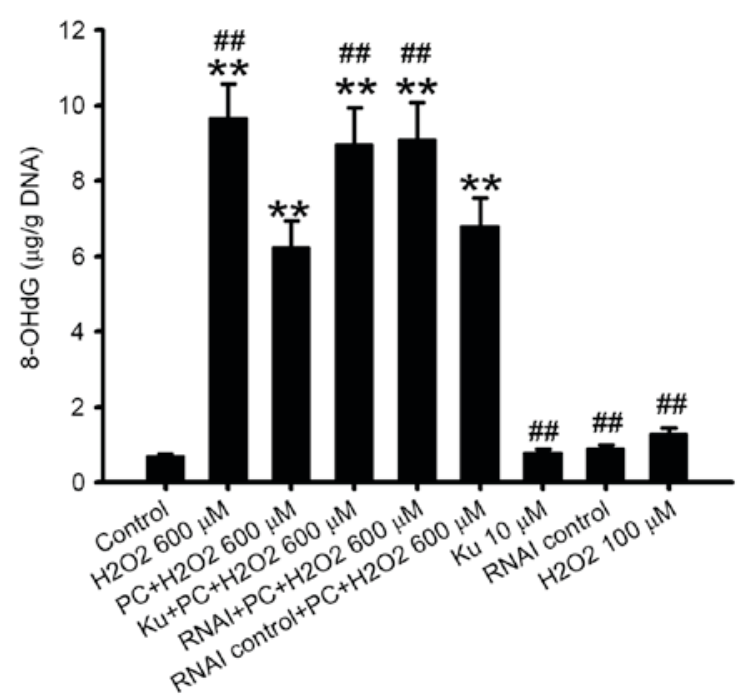

Figure 5. Effect of various treatments on 8-OHdG levels in Neuro-2a cells, as determined using a 8-OHdG ELISA assay. Data are expressed as the mean \pm standard error $(\mathrm{n}=5)$. ${ }^{* *} \mathrm{P}<0.01$ vs. control; ${ }^{\# \#} \mathrm{P}<0.01$ vs. $\mathrm{PC}+600 \mu \mathrm{M}$ $\mathrm{H}_{2} \mathrm{O}_{2}$. 8-OHdG, 8-hydroxy-2'-deoxyguanosine; PC, preconditioned with $100 \mu \mathrm{M} \mathrm{H}_{2} \mathrm{O}_{2} ; \mathrm{Ku}, \mathrm{Ku} 55933$; RNAi, RNA interference with small interfering RNA; RNAi control, control small interfering RNA.

and $\mathrm{P}<0.01$, respectively; Fig. 4) and the decrease in $8-\mathrm{OHdG}$ content observed following preconditioning with $100 \mu \mathrm{M} \mathrm{H}_{2} \mathrm{O}_{2}$ was also inhibited by pretreatment with the ATM inhibitor 

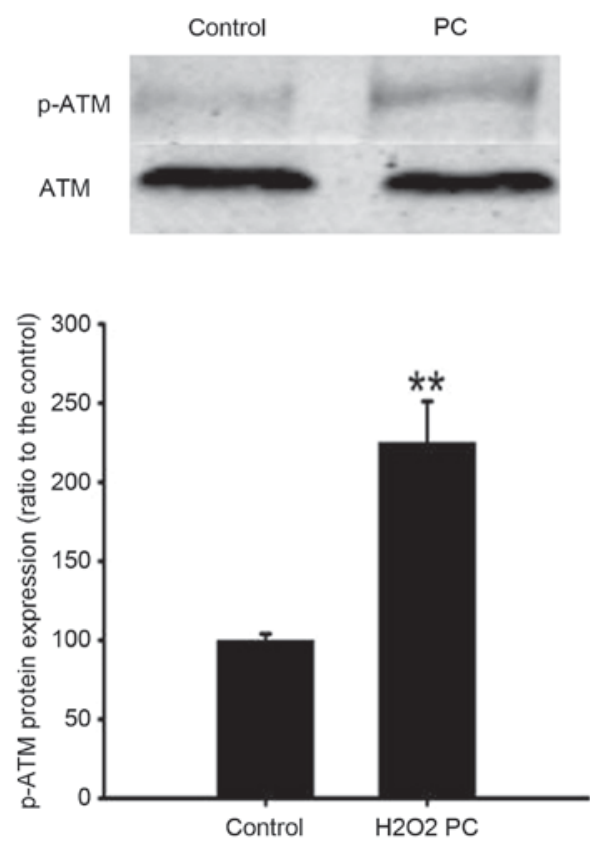

Figure 6. Effect of $\mathrm{H}_{2} \mathrm{O}_{2}$ preconditioning on p-ATM expression, as determined by western blot analysis. Data are expressed as the mean \pm standard error ( $\mathrm{n}=3-5) .{ }^{* *} \mathrm{P}<0.01$ vs. control. p-, phosphorylated; ATM, ataxia-telangiectasia mutated; $\mathrm{PC}$, preconditioned with $100 \mu \mathrm{M} \mathrm{H}_{2} \mathrm{O}_{2}$.

Ku55933 or silencing of ATM with RNAi compared with the preconditioned group $(\mathrm{P}<0.01$ and $\mathrm{P}<0.01$, respectively; Fig. 5).

\section{Discussion}

The results of the present study revealed that $\mathrm{H}_{2} \mathrm{O}_{2}$ preconditioning protects $\mathrm{N} 2$ a cells against oxidative stress-induced injury, $\mathrm{H}_{2} \mathrm{O}_{2}$ preconditioning upregulates ATM mRNA and protein expression levels, and pretreatment with an ATM inhibitor or knockdown of ATM abrogates the protective effects of $\mathrm{H}_{2} \mathrm{O}_{2}$ preconditioning against lethal $\mathrm{H}_{2} \mathrm{O}_{2}$-induced cell injury. This demonstrated that ATM may mediate the protective effects of $\mathrm{H}_{2} \mathrm{O}_{2}$ preconditioning.

Oxidative stress induced by ROS is a primary cause of ischemia/reperfusion injury; however, previous studies have reported that ROS generated from brief ischemia/reperfusion events triggers preconditioning-like protection. Brief exposure to exogenous oxygen species protected PC12 cells and neurons against subsequent serious oxidative stress injury via opening of surface $\mathrm{K}_{\mathrm{ATP}}$ channels (20), increasing expression of Bcl-2 (1) and hypoxia-inducible factor- $1 \alpha$ protein (21), or enhancing the expression and functional activities of volume-activated chloride channels (22). The present study observed that $\mathrm{H}_{2} \mathrm{O}_{2}$ preconditioning protected against oxidative stress-induced injury in N2a cells, as assessed by MTT assays, flow cytometry, and analysis of capase-3 activity and 8-OHdG content.

Although numerous previous studies have been performed, the cellular and molecular mechanisms underlying preconditioning remain to be fully clarified. A previous study reported that activation of ATM regulates cell redox homeostasis in various w ays, including the enhancement of glucose-6-phosphate dehydrogenase activity, thereby increasing the
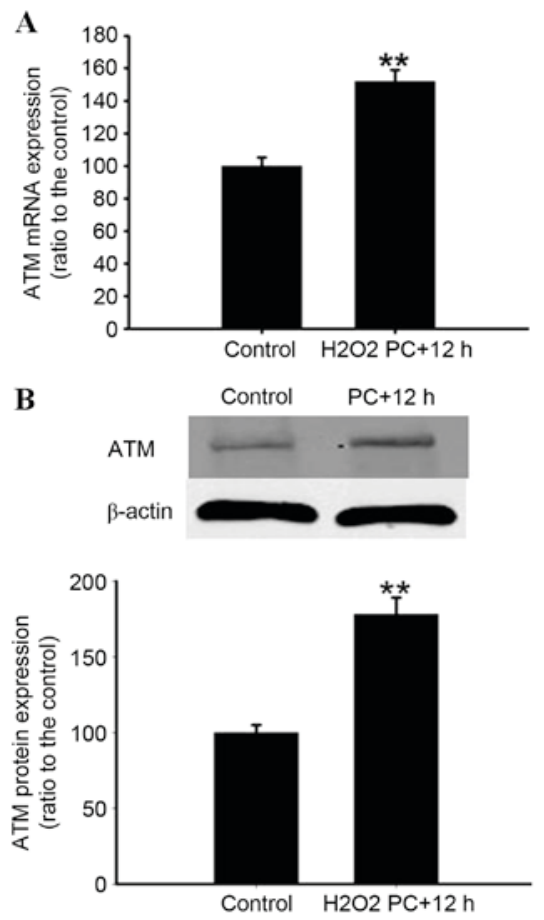

Figure 7. Effect of $\mathrm{H}_{2} \mathrm{O}_{2}$ preconditioning on (A) ATM mRNA and (B) protein expression levels. Data are expressed as the mean \pm standard error $(n=3-5)$. ${ }^{* *} \mathrm{P}<0.01$ vs. control. ATM, ataxia-telangiectasia mutated; PC, preconditioned with $100 \mu \mathrm{M} \mathrm{H}_{2} \mathrm{O}_{2}$.

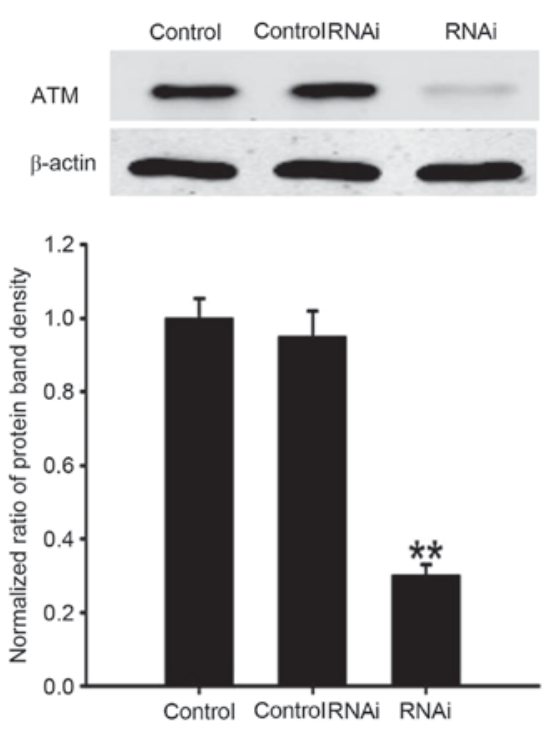

Figure 8. ATM protein expression levels are downregulated by RNAi. Data are expressed as the mean \pm standard error $(n=3) .{ }^{* *} \mathrm{P}<0.01$ vs. control. ATM, ataxia-telangiectasia mutated; RNAi, RNA interference with small interfering RNA; RNAi control, control small interfering RNA.

intracellular nicotinamide adenine dinucleotide phosphate and glutathione content significantly (10). ATM-deficient lymphoid stem cells exhibit mitochondrial dysfunction and a significant increase in ROS; exogenous ATM restores mitochondrial function and reduces the generation of ROS (23). ATM is additionally present in the peroxisomes, regulating catalase activity (24). Previous studies have reported that when PC12 cells or neurons were subjected to metabolic stress including 
serum starvation, ATM regulated the insulin-associated signaling pathway and inhibited neuronal apoptosis $(25,26)$. In addition, a previous study indicated that histone acetyltransferase 4 accumulates more readily in the nuclei of ATM-deficient neurons, and inhibits myocyte enhancer factor $2 \mathrm{~A} /$ cyclic adenosine monophosphate response element binding-dependent transcription to promote neurodegeneration (27). Based on these findings, ATM is regarded as an essential endogenous protective protein against stress (4).

As the preconditioning process induces endogenous protective mechanisms, it was hypothesized that ATM may be involved in $\mathrm{H}_{2} \mathrm{O}_{2}$ preconditioning. Therefore, the effect of $\mathrm{H}_{2} \mathrm{O}_{2}$ preconditioning on the expression levels of ATM was measured. Notably, $\mathrm{H}_{2} \mathrm{O}_{2}$ preconditioning was observed to increase the protein expression levels of p-ATM, which indicated that $\mathrm{H}_{2} \mathrm{O}_{2}$ preconditioning activated ATM. Following $\mathrm{H}_{2} \mathrm{O}_{2}$ preconditioning for $12 \mathrm{~h}$, ATM mRNA and protein expression levels increased, which supported this hypothesis. Additionally, the ATM inhibitor Ku55933, or knockdown of ATM using RNAi, attenuated the protective effect of $\mathrm{H}_{2} \mathrm{O}_{2}$ preconditioning against oxidative stress-induced injury. These data suggested that ATM is involved in $\mathrm{H}_{2} \mathrm{O}_{2}$ preconditioning.

In conclusion, the results of the present study demonstrated, to the best of our knowledge for the first time, that $\mathrm{H}_{2} \mathrm{O}_{2}$ preconditioning activates ATM and upregulates ATM mRNA and protein expression levels in N2a cells. Treatment with the ATM inhibitor, Ku55933, or silencing of ATM with RNAi attenuated the protective effect of $\mathrm{H}_{2} \mathrm{O}_{2}$ preconditioning in $\mathrm{N} 2$ a cells. These results provide insight into the mechanisms underlying the involvement of ATM in $\mathrm{H}_{2} \mathrm{O}_{2}$ preconditioning. In addition, the present study highlights the potential of the ATM protein as a key therapeutic target for the prevention and treatment of ischemic brain damage.

\section{Acknowledgements}

The present study was supported by the National Nature Science Foundation of China (grant no. 81301057 to J.H.W. and grant no. 30971428 to D.F.W), the Foundation of Health and Family Planning Commission of Hubei province (grant no. WJ2015MB029 to D.F.W) and the Chenguang Plan of Wuhan Municipal Science and Technology Bureau (grant no. 2014070404010226 to J.L.).

\section{References}

1. Tang XQ, Feng JQ, Chen J, Chen PX, Zhi JL, Cui Y, Guo RX and Yu HM: Protection of oxidative preconditioning against apoptosis induced by $\mathrm{H} 2 \mathrm{O} 2$ in $\mathrm{PC} 12$ cells: Mechanisms via MMP, ROS, and Bcl-2. Brain Res 1057: 57-64, 2005.

2. León OS, Menéndez S, Merino N, Castillo R, Sam S, Pérez L, Cruz E and Bocci V: Ozone oxidative preconditioning: A protection against cellular damage by free radicals. Mediators Inflamm 7: 289-294, 1998.

3. Shiloh Y: ATM and related protein kinases: Safeguarding genome integrity. Nat Rev Cancer 3: 155-168, 2003.

4. Bhatti S, Kozlov S, Farooqi AA, Naqi A, Lavin M and Khanna KK: ATM protein kinase: The linchpin of cellular defenses to stress. Cell Mol Life Sci 68: 2977-3006, 2011.

5. Kuang X, Yan M, Ajmo JM, Scofield VL, Stoica G and Wong PK: Activation of AMP-activated protein kinase in cerebella of Atm-/-mice is attributable to accumulation of reactive oxygen species. Biochem Biophys Res Commun 418: 267-272, 2012.
6. Kamsler A, Daily D, Hochman A, Stern N, Shiloh Y, Rotman G and Barzilai A: Increased oxidative stress in ataxia telangiectasia evidenced by alterations in redox state of brains from Atm-deficient mice. Cancer Res 61: 1849-1854, 2001.

7. Kim TS, Kawaguchi M, Suzuki M, Jung CG, Asai K, Shibamoto Y, Lavin MF, Khanna KK and Miura Y: The ZFHX3 (ATBF1) transcription factor induces PDGFRB, which activates ATM in the cytoplasm to protect cerebellar neurons from oxidative stress. Dis Model Mech 3: 752-762, 2010.

8. Frappart PO and McKinnon PJ: Ataxia-telangiectasia and related diseases. Neuromolecular Med 8: 495-511, 2006.

9. Hoche F, Seidel K, Theis M, Vlaho S, Schubert R, Zielen S and Kieslich M: Neurodegeneration in ataxia telangiectasia: What is new? What is evident? Neuropediatrics 43: 119-129, 2012.

10. Cosentino C, Grieco D and Costanzo V: ATM activates the pentose phosphate pathway promoting anti-oxidant defence and DNA repair EMBO J 30: 546-555, 2011.

11. Dobbin MM, Madabhushi R, Pan L, Chen Y, Kim D, Gao J, Ahanonu B, Pao PC, Qiu Y, Zhao Y and Tsai LH: SIRT1 collaborates with ATM and HDAC1 to maintain genomic stability in neurons. Nat Neurosci 16: 1008-1015, 2013.

12. Khanna KK, Lavin MF, Jackson SP and Mulhern TD: ATM, a central controller of cellular responses to DNA damage. Cell Death Differ 8: 1052-1065, 2001.

13. Ditch S and Paull TT: The ATM protein kinase and cellular redox signaling: Beyond the DNA damage response. Trends Biochem Sci 37: 15-22, 2012.

14. Li MJ, Wang WW, Chen SW, Shen Q and Min R: Radiation dose effect of DNA repair-related gene expression in mouse white blood cells. Med Sci Monit 17: BR290-BR297, 2011.

15. Li JZ, Wu JH, Yu SY, Shao QR and Dong XM: Inhibitory effects of paeoniflorin on lysophosphatidylcholine-induced inflammatory factor production in human umbilical vein endothelial cells. Int J Mol Med 31: 493-497, 2013.

16. Livak KJ and Schmittgen TD: Analysis of relative gene expression data using real-time quantitative PCR and the 2(-Delta Delta C(T)) Method. Methods 25: 402-408, 2001.

17. Alnemri ES, Livingston DJ, Nicholson DW, Salvesen G, Thornberry NA, Wong WW and Yuan J: Human ICE/CED-3 protease nomenclature. Cell 87: 171, 1996.

18. Ghavami S, Hashemi M, Ande SR, Yeganeh B, Xiao W, Eshraghi M, Bus CJ, Kadkhoda K, Wiechec E, Halayko AJ and Los M: Apoptosis and cancer: Mutations within caspase genes. J Med Genet 46: 497-510, 2009.

19. Zhang N, Komine-Kobayashi M, Tanaka R, Liu M, Mizuno Y and Urabe T: Edaravone reduces early accumulation of oxidative products and sequential inflammatory responses after transient focal ischemia in mice brain. Stroke 36: 2220-2225, 2005.

20. Tang XQ, Chen J, Tang EH, Feng JQ and Chen PX: Hydrogen peroxide preconditioning protects $\mathrm{PC} 12$ cells against apoptosis induced by oxidative stress. Sheng Li Xue Bao 57: 211-216, 2005.

21. Chang S, Jiang X, Zhao C, Lee C and Ferriero DM: Exogenous low dose hydrogen peroxide increases hypoxia-inducible factor-1alpha protein expression and induces preconditioning protection against ischemia in primary cortical neurons. Neurosci Lett 441: 134-138, 2008.

22. Zhu L, Zuo W, Yang H, Zhang H, Luo H, Ye D, Lin X, Mao J, Feng J, Chen L and Wang L: Involvement of volume-activated chloride channels in $\mathrm{H} 2 \mathrm{O} 2$ preconditioning against oxidant-induced injury through modulating cell volume regulation mechanisms and membrane permeability in PC12 cells. Mol Neurobiol 48: 205-216, 2013.

23. Ambrose M, Goldstine JV and Gatti RA: Intrinsic mitochondrial dysfunction in ATM-deficient lymphoblastoid cells. Hum Mol Genet 16: 2154-2164, 2007.

24. Watters D, Kedar P, Spring K, Bjorkman J,Chen P, Gatei M, Birrell G, Garrone B, Srinivasa P, Crane DI and Lavin MF: Localization of a portion of extranuclear ATM to peroxisomes. J Biol Chem 274: 34277-34282, 1999.

25. Li Y, Xiong H and Yang DQ: Functional switching of ATM: Sensor of DNA damage in proliferating cells and mediator of Akt survival signal in post-mitotic human neuron-like cells. Chin J Cancer 31: 364-372, 2012.

26. Yang DQ, Halaby MJ, Li Y, Hibma JC and Burn P: Cytoplasmic ATM protein kinase: An emerging therapeutic target for diabetes, cancer and neuronal degeneration. Drug Discov Today 16: 332-338, 2011.

27. Li J, Chen J, Ricupero CL, Hart RP, Schwartz MS, Kusnecov A and Herrup K: Nuclear accumulation of HDAC4 in ATM deficiency promotes neurodegeneration in ataxia telangiectasia. Nat Med 18: 783-790, 2012. 